\title{
The Success Factors of Web Integrated Library System and Job Satisfaction in Academic Libraries
}

\author{
Mawar Noor Binti Abdullah \\ Perpustakaan Tun Dr Ismail, Universiti Teknologi MARA Johor Branch, \\ Segamat Campus, 85000, Malaysia \\ Corresponding author email: mawar146@uitm.edu.my \\ DOI: https://doi.org/10.24191/aclim.v1i1.4
}

Received: 26/1/2021 / Accepted: 7/5/2021 / Published Online: 15/7/2021

\begin{abstract}
Web integrated library system performance is important to evaluate as it is used in managing library activities and holds millions of library records. To have an effective web integrated library system for staff, it is essential for the library to offer high quality systems, service, usage and Internet. This study presents a perception on web integrated library system success factors (system quality, service quality, usage quality and Internet quality) and its relationships with job satisfaction. Questionnaires was distributed to 110 library staff who are using the web integrated library system at academic libraries in Selangor, Melaka, Johor, Negeri Sembilan and Pahang. The analyses are undertaken using SPSS. Descriptive findings show moderate perceptions in four variables (system quality, service quality, usage quality and job satisfaction) where the mean value are in the range 3.18 to 3.45 and low perception in one variable (Internet quality) in range 2.69 on a 5-point Likert. Besides that, the results also indicate a positive and high correlation between job satisfaction with usage quality, moderate correlation between service quality and Internet quality. Meanwhile, the relationship between job satisfaction and system quality is weak. The finding of the study is useful for the library to realize that the success factor of a web integrated library system will contribute to their job satisfaction. As to that, the library should improve their library information system to provide a high quality of library product and services.
\end{abstract}

Keywords: success factor; Web Integrated Library System; job satisfaction; information system success; information system evaluation.

\section{0 INTRODUCTION}

Academic libraries can benefit from powerful workflow library management as well as flexible and convenient access to information by using a web integrated system. The development of effective information delivery is a key component of university teaching and learning and modern technology. Academic libraries used various software packages to automate their operations as to manage huge collections of printed and non-printed materials. Integrated library systems like other technologies, are playing an essential role in facilitating libraries in running their operations more quickly and efficiently (Siddique and Mahmood, 2014). Thus a good quality of library information system may lead to their staff job satisfaction. Library management systems are established as an essential tool in the support of effective customer services, stock management and management of services offered by libraries (Madhusudhan \& Singh, 2016). Most of the vendors of library management systems on the market had products which were introduced as systems of the third generation. They all looked more or less the same, both inside and outside, as they were designed following the same pattern, but none of them was or is completely finished (Dahl, 2002).

Evaluation had generally been accepting as an essential element for measuring and ensuring effectiveness and efficiency in library system. An assessment of different library systems is essential before selecting and implementing an appropriate one; it is also necessary to evaluate a system after it had been implemented and operational for a significant period. This is done to check whether or not the system is performing to expectation, its functionality and the important problems. Evaluation research not only analyses the usability and usefulness but also 
the performance of the system (Taole, 2008). Besides that, Aggelidis \& Chatzoglou (2012) acknowledge that measuring job satisfaction had a long history within the information system discipline.

This research is guided by the following objectives:

i) to determine the success factor of WILS pertaining to system quality, service quality, usage satisfaction, Internet quality and job satisfaction.

ii) to examine the relationship between system quality, service quality, usage satisfaction, Internet quality and job satisfaction.

There are four hypotheses developed in this study in order to test the relationship between WILS success factor and job satisfaction.

i) there is significant relationship between system quality and job satisfaction

ii) there is significant relationship between service quality and job satisfaction

iii) there is significant relationship between usage quality and job satisfaction

iv) there is significant relationship between Internet quality and job satisfaction

This study adapted the Information System Success Model developed by DeLone and McLean in 1992 and updated in 2003 to fill the gap of study related to evaluation of web integrated library systems in Malaysia. It also examined the impact of Internet connection factor to job satisfaction. This is because there might be a slightly different set of satisfaction in terms of access using intranet and Internet/web based information systems. It also provided an academic library in Malaysia with a better idea in recognizing the effectiveness of chosen web integrated library systems for their library operations and their staff job satisfaction. The result of this study contributed to academic libraries in evaluating their library system and the revision of this system helped management decide whether this web integrated library system relevant to their library in order to cope with the advancement of technology and at the same time provide better services to user and staff.

\section{0 LITERATURE REVIEW}

The research framework used in this study is modified from the Information System Success Model by DeLone and McLean's to identify the variables used in the research and questionnaire with the addition of internet quality variables. Figure 1 presents dependent and independent variables that are used in this study. This framework assists in clarifying the proposed links between success factor of WILS and job satisfaction.

\section{Success factor of WILS}

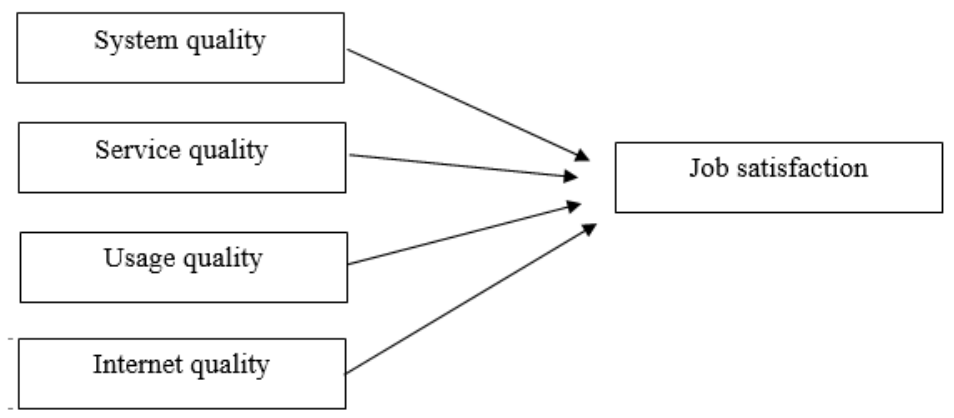

Independent variables

Dependent variable

Figure 1: Theoretical framework

The success factors are usually listed as either very general factors or very specific factors affecting a particular project (Belassi and Tukel, 1996). It describes the impacts of several aspects on system performance thus helps the organization to improve or take any related actions in future. The success of an information system is not only dependent on high technology but also on user successful use of the system and job satisfaction. 


\subsection{System quality}

There is a need for a high quality of library management system as academic libraries need to serve their users all around the country with accurate and complete information to support the teaching, learning and research activities. WLIS needs to have a comprehensive module and contains all system features and functions whether in an acquisition, cataloguing, circulation, serials, binding and article module. The functionality and efficiency of the integrated library system is critical to the smooth operation of information systems in fulfilling library client charter as to provide access to information at anytime and anywhere.

System quality refers to the quality of information processing offering key functions and features. It is also related to the technical aspect of software that is user-friendly, easy to cope with and maintain (Gorla, Somers and Wong, 2010). An instrument in system quality is explained by DeLone and McLean (2003) as consisting of ease of use, functionality, reliability, data quality, flexibility and integration. Zaied (2012) in his study revealed that measurement of system quality focuses on system performance characteristics, resource utilization and investment, response time, system trust and accuracy.

Additionally, the element of reliability, usability, adaptability, trust and maintainability are also highlighted. The complete system features can support the ability to store data and make data easy to retrieve by the system's users. Fox et al. (1993) stated that in the field of library and information science, specific features are believed to be critical in affecting the usage of libraries system. Without the complete system features, staff will face difficulties in processing and managing a large amount of library collections. In Yu and Qian (2018) study, they explained that system quality indicates the overall system performance as perceived by users.

\subsection{Service quality}

In today's world of intense competition, the key to sustain in competitive advantages lies in delivering high quality of service that will result in satisfied customers (Shemwell et al., 1998). The service quality is also one of the highly debated and researched topics in marketing theory and has been described as a form of attitude in responding to a favorable or unfavorable way of an object. After sales service is critical for system vendors to fulfill as for supporting any requirement from users of the system. Their services help academic libraries to minimize any error or problems regarding the use of WILS.

At the early phase of WILS implementation and data migration, difficulties occur and library staff are unfamiliar with the term used in WILS modules. Concurrent with this scenario, the Information Technology department is responsible to manage feedback from library staffs. In order to cope with this, academic libraries had setup team expert and technical team to support any additional requirement and look into the feedback. All the feedback is recorded and monitored in a feedback platform named iSMS. This due to the progressive action and monitoring action by the Chief Librarian to ensure all feedback on WILS must take action as soon as possible to avoid any service interruption and to make sure the objectives of the library are achieved to serve a comprehensive, up to date and relevant knowledge resources.

As stated by Petter et al. (2008), service quality concentrates on the level of service delivered by system providers to users in terms of reliability, responsiveness, assurance and empathy factor. It also had to meet user expectation and satisfaction by providing service in time and courteous when dealing with the request. This required a knowledgeable person in charge to solve any system problem and ensure error-free on system performance. The research literature on service quality had identified numerous models by the different researchers. Parasuraman et al. (1988) develop a comprehensive SERVQUAL instrument on 22 items work of service quality and value which measure by five-factors namely reliability, responsiveness, assurance, empathy and tangibles.

According to Adil (2013) from customers' perspective, service quality significantly influences their satisfaction by providing fast service, understanding the needs, available when needed, empowered to resolve problems and lastly shows sincere interest in solving problems. Likewise, study conducted by Adil (2013) itemized service quality as up to date equipment, services delivered at promised time, services delivered as promised, error-free records, service right at the first time, solving the problem, trustworthy, courteous, knowledgeable, prompt service, willing to help, individual attention, specific needs and best interest.

\subsection{Usage quality}

Usage is the degree and manner in which staff utilize the capabilities of an information system by the amount of use, frequency and extent of use. Venkatesh et al. (2012) justify intention to use is determined by the user's beliefs 
about the system. Furthermore, TAM model enables the acceptance of technology by considering behavioral intention to use and actual system use of the information system (Davis, 1989). The previous study explains the acceptance of library information system are based on factor analysis of perceived usefulness and ease of use. It contains an indicator of the quality of work, control over work, work more quickly, critical to the job, increase productivity, job performance, accomplish more work, effectiveness, makes job easy and useful for perceived usefulness. While indicator perceived ease of use are; cumbersome, easy of learning, frustrating, controllable, rigid and inflexible, easy of remembering, mental effort, understandable, effort to be skillful and ease of use (Endang, 2015). Petter, DeLone and McLean (2008) described the value of information system to the success of individual, group, organization in improving the decision making, productivity, increase sales, cost reduction, and increase profit.

The value also includes the efficiencies use in internal operation, effective management of resources, improve customer service and improve decision making (Gorla, Somers and Wong, 2010). Moreover, this use takes account the individual satisfaction and organization performance in creating competitive advantage and strategic value (Mahmood and Soon, 1991). A study conducted by Burton-Jones in 2005 discovered the sampling of 48 articles in major information system journals in the period 1977-2005 that explain the usage as an activity that involves three elements; a user, a system and a task. System usage is measure by the number of systems sessions, the percentage of times use to perform a task, duration of use, number of times system use and voluntariness of use. There are many conceptions of system usage at the individual, group, and organizational levels, with most researchers conceptualizing system usage as a behavior (what a user does), cognition (what a user thinks), and/or an effect (what a user feels).

At the individual level, most researchers view system usage as behavior, measuring system usage via indicators such as an individual's frequency or duration of usage (Trice and Treacy 1986). Therefore, in term of usage quality the items measured consists of enjoyable, convenience to learn, recommended to others, intended to use in future and most importantly easy to use.

\section{$2.4 \quad$ Internet quality}

The Internet is a global computer network providing a variety of information and communication facilities, consisting of interconnected networks using standardized communication protocols (Oxford, 2018). The Internet enables network of global exchanges including private, public, business, academic and government. The Internet is used as a global communication system, including hardware and infrastructure. As computing advanced, communication was gradually delivered and enhanced.

Nowadays, billions of Internet users rely on multiple application and networking technologies to do their daily business and social activities. The Internet is the most cost-effective communications method in the world, in which the data transfer and file-sharing services are instantly available (Technopedia, 2018). By taking these advantages, many businesses and organization are moving forward to use cloud computing services and integrated system. In order for the service and system to work effectively, the high quality of Internet connection is crucial. A study conducted by Lahrssen (2018) describe that the speed and bandwidth of Internet is affected by the number of users on the network. In order to effectively handle organization activities, a high speed of Internet connection is required.

Moreover, Internet permits the secure point to point connection over network for data protection. As to use cloud processes efficiently, organizations need dependable high-speed Internet. Being able to put organization processes in the cloud keeps expenses down and productivity high. With fast Internet connection, it makes easy to connect and interact with other staff in organization despite their current location. In addition, the high speed of connection can eliminate many potential telecommunication problems, like slow Internet speeds during heavy use and slow uploads of important files. Similarly, Ahmed (2017) agreed that the faster Internet speed, the more we can accomplish business goals, high quality and efficient organization process.

With a high speed of Internet connection, the average page loading times are majorly reduced. When the Internet does not have high speed capability, the connection becomes slow when more than one user tries to browse the web at the same time. Above all, without high-speed, sufficient and stable internet connection, the organization may face a trouble in digital business operations and obstruction towards success.

\subsection{Job satisfaction}

Satisfaction is considered as a prerequisite for staff retention, loyalty and helps in profitability and return on 
investment (Hackl and Westlund, 2000). It can occur at multiple levels based on the function that encounters/experiences of the staff in an organization. Measuring satisfaction on system performance has great potential to provide a library with information about their actual staff performance and their expectations. Such information also allows vendors to fine-tune their efforts to improve the quality of their services or to deliver services that appear attractive to system users (Shin \& Elliott, 2001).

In this manner, measuring job satisfaction of library staff when using WILS is expected to enhance the library reputation and image, increase attention to staff needs, reduce staff attrition (Muffato \& Panizzolo, 1995) and ultimately increase profitability. Besides, one of the information system success objectives is to satisfy its users by meet their needs and achieve their expectations. This can be done by capturing the behavior that affects satisfaction by looking at the usefulness element. The successful system can assist users to contribute values to the internal and external customer. In Seddon and Kiew's model, usefulness is believed to affect satisfaction but in some situations, satisfaction is thought to be a better alternative for success than actual use (Jones and Beatty, 2001). Many researchers such as William and Anderson (1991) emphasized that satisfaction consists of a cognitive and affective component which include behavioral action or thinking and emotional attitude.

Other than that, job satisfaction consists of meet the information processing needs, sufficient system, effective system, well satisfied with the system as a whole, helps improving capabilities to meet the needs of the target group, help create value for users and allow more user orientation. While, a study conducted by Zaied (2012) explained the element of measuring user satisfaction specifically on job satisfaction are self-efficacy, repeat visit, personalization, perceived risk and enjoyment. In terms of use of information systems, the other popular element on job satisfaction includes; it would help to complete work/task assign, has met certain expectations, improve productivity, improve decision making or problem-solving and saves time.

\subsection{METHODOLOGY}

The quantitative study was conducted in order to test the hypotheses in this study. Online survey via Google Forms is used for data collection. The online survey URL link and information is emailed to the respondents due to save time, quick and easy feedback, expenses and overcoming geographic distance. The participants in this study are 150 academic libraries staff from gred N11 to S54 (deputy chief librarian, librarian, assistant librarian) in Selangor, Melaka, Johor, Negeri Sembilan and Pahang. They are from different departments who use web integrated library management system in their daily operation and activities.

This study is referring to Krejcie and Morgan table to achieve desired sample size. A number of 110 questionnaires were gathered and available for analysis. The research instrument consisted of two main sections. The first section incorporates a nominal scale to identify respondents' demographic information. The second section uses 5 points Likert response scale where 5: Strongly disagree, 4: Disagree, 3: Neutral, 2: Agree and 1: Strongly agree. This section includes Information System Success concepts. The data received from the questionnaires are coded and entered onto the SPSS statistical program (SPSS Version 24.0 for Windows). The data are subjected to descriptive analysis, validity and reliability test and correlation test.

\subsection{RESULT}

\section{Reliability Analysis}

Reliability generally refers to the extent to which a variable or set of variables is consistent in what it is intended to measure. Based on the Table 1, the value of Cronbach's Alpha for system quality was 0.89 , service quality was 0.94 , usage quality was 0.94 , Internet quality was 0.80 and the job satisfaction was 0.92 . According to all of the value, all variables are stated more than 0.5 value of Cronbach Alpha which means that all the instruments of the study were trustworthy and reliable. Therefore, it can be used for further analysis.

\begin{tabular}{|l|l|l|l|}
\hline & Variables & Cronbach's Alpha & No. of item \\
\hline 1 & System quality & 0.89 & 3 \\
\hline 2 & Service quality & 0.94 & 5 \\
\hline
\end{tabular}




\begin{tabular}{|l|l|l|l|}
\hline 3 & Usage quality & 0.94 & 5 \\
\hline 4 & Internet quality & 0.80 & 3 \\
\hline 5 & Job satisfaction & 0.92 & 5 \\
\hline
\end{tabular}

Table 1: Reliability test

\section{Perception on success factor of WILS pertaining to system quality}

System quality is the desirable characteristics of an information system such as ease of use, ease of learning, flexibility, reliability as well as system features of sophistication, and response times. System quality is also a value of the system performance and desirable characteristics of information system. Table 2 shows the mean score of system quality was moderate in which library staff were agree that WILS has all features $($ mean $=3.45)$, WILS is integrated $($ mean $=3.34)$ and WILS is well structured (3.27).

\begin{tabular}{|c|c|c|c|}
\hline & Statement & Mean & Std. Deviation \\
\hline 1 & WILS has all features & 3.45 & 0.95 \\
\hline 2 & WILS is well structured & 3.27 & 0.93 \\
\hline \multirow[t]{2}{*}{3} & WILS is integrated & 3.34 & 0.91 \\
\hline & Overall & 3.35 & 0.83 \\
\hline
\end{tabular}

Table 2: Mean score of system quality

\section{Perception on success factor of WILS pertaining to service quality}

Service quality is the quality of the support that system users receive from the IS department and IT support personnel for example in term of responsiveness, accuracy, reliability, technical competence, and empathy of the personnel staff. Table 3 shows the mean score of service quality was moderate. Library staff were agreeing that the staff of technical support for WILS shows sincere interest in solving problems (mean = 3.52), the staff of technical support for WILS provides fast service (mean = 3.5), the staff of technical support for WILS empowered to resolve problems (mean = 3.44), the staff of technical support for WILS available when needed $($ mean $=3.42)$, the staff of technical support for WILS understand the needs (mean = 3.39).

\begin{tabular}{llll} 
& Statement & Mean & Std. Deviation \\
\hline 1 & The staff of technical support for WILS provides fast service & 3.51 & 0.91 \\
\hline 2 & The staff of technical support for WILS understand the needs & 3.39 & 0.88 \\
\hline 3 & The staff of technical support for WILS available when needed & 3.42 & 0.94 \\
\hline 4 & $\begin{array}{l}\text { The staff of technical support for WILS empowered to resolve } \\
\text { problems }\end{array}$ & 3.44 & 0.99 \\
\hline $\begin{array}{l}\text { The staff of technical support for WILS shows sincere interest in } \\
\text { solving problems }\end{array}$ & 3.52 & 0.98 \\
\hline & Overall & $\mathbf{3 . 4 5}$ & $\mathbf{0 . 8 2}$ \\
\hline
\end{tabular}

Table 3: Mean score of service quality

\section{Perception on success factor of WILS pertaining to usage quality}

System use is the amount and routine in which staff utilize the capabilities of an information system. For example, the amount, frequency, nature, appropriateness, extent and purpose of use. It describes how well the outputs 
of information are used. Table 4 shows the mean score of usage quality in which the overall score is 3.12. Library staff was agreed that WILS is intended to use in future (mean =3.34), WILS is convenience to learn (mean $=3.15)$, WILS is easy to use $($ mean $=3.14)$, WILS is recommended to others $($ mean $=3.00)$ but disagree on WILS is enjoyable $($ mean $=2.96)$.

\begin{tabular}{llll}
\multicolumn{2}{c}{ Statement } & Mean & Std. Deviation \\
\hline 1 & WILS is easy to use & 3.14 & 0.95 \\
\hline 2 & WILS is convenience to learn & 3.15 & 1.01 \\
\hline 3 & WILS is recommended to others & 3.00 & 1.02 \\
\hline 4 & WILS is intended to use in future & 3.34 & 1.04 \\
\hline 5 & WILS is enjoyable & 2.96 & 1.00 \\
\hline & Overall & $\mathbf{3 . 1 2}$ & $\mathbf{0 . 9 0}$ \\
\hline
\end{tabular}

Table 4: Mean score of usage quality

\section{Perception on success factor of WILS pertaining to internet quality}

Internet quality refers to the speed and establishment of Internet connection when using the information system. Table 5 shows the mean score of Internet quality is 2.69. Library staff disagree that Internet connection at my workstation is sufficient $($ mean $=2.79)$, Internet connection at my workstation is stable $($ mean $=2.70)$ and Internet connection at my workstation is high speed (mean $=2.58)$.

\begin{tabular}{llll} 
& Statement & Mean & Std. Deviation \\
\hline 1 & Internet connection at my workstation is high speed & 2.58 & 0.95 \\
\hline 2 & Internet connection at my workstation is sufficient & 2.79 & 1.02 \\
\hline 3 & Internet connection at my workstation is stable & 2.70 & 0.96 \\
\hline Overall & $\mathbf{2 . 6 9}$ & $\mathbf{0 . 8 7}$ \\
\hline
\end{tabular}

Table 5: Mean score of Internet quality

\section{Perception on success factor of WILS pertaining to job satisfaction}

Job satisfaction describes as the feelings, attitudes or preferences of individuals regarding their work. It consists the overall satisfaction on system and library staff approval or disapproval of WILS. Job satisfaction is also a major source of determining the success of library information system. Table 6 shows the mean score of job satisfaction with overall mean of 3.18. The library staff agreed that WILS helps to complete my work $($ mean $=3.36)$, followed by WILS improves my decision (mean =3.32), WILS improved productivity $($ mean $=3.17)$, WILS saves my time $($ mean $=3.05)$ and last but not least, slightly disagree on WILS has met my expectations $($ mean $=2.97)$.

\section{$\begin{array}{lll}\text { Statement Mean Std. Deviation } & \text { Mean }\end{array}$}

\begin{tabular}{llll}
\hline 1 & WILS helps to complete my work & 3.36 & 0.81 \\
\hline 2 & WILS has met my expectations & 2.97 & 0.83 \\
\hline 3 & WILS improved productivity & 3.17 & 0.93 \\
\hline 4 & WILS improves my decision & 3.32 & 0.87 \\
\hline 5 & WILS saves my time & 3.05 & 1.11 \\
\hline & Overall & $\mathbf{3 . 1 8}$ & $\mathbf{0 . 7 9}$ \\
\hline
\end{tabular}

Table 6: Mean score of job satisfaction 


\section{Relationship between WILS success factor and job satisfaction}

Table 7 shows the correlation between five dimensions of WILS success factor and job satisfaction. There were a positive and high correlation between job satisfaction with use quality $(\mathrm{r}=0.789 ; \mathrm{p}<0.01)$ and moderate correlation on service quality $(r=0.582 ; \mathrm{p}<0.01)$ and Internet quality $(\mathrm{r}=0.482 ; \mathrm{p}<0.01)$. However, there were positive but low correlation between job satisfaction with system quality $(\mathrm{r}=0.340 ; \mathrm{p}<0.01)$.

\begin{tabular}{llllll} 
& SYSQ & SRVQ & USEQ & INTQ & JOBQ \\
\hline System quality & 1 & & & & \\
\hline Service quality & $.660^{* *}$ & 1 & & & \\
\hline Usage quality & $.520^{* *}$ & $.591^{* *}$ & 1 & & \\
\hline Internet quality & $.215^{*}$ & $.257^{* *}$ & $.419^{* *}$ & 1 & \\
\hline Job satisfaction & $\mathbf{. 3 4 0}^{* *}$ & $\mathbf{. 5 8 2}^{* *}$ & $\mathbf{. 7 8 9}^{* *}$ & $\mathbf{. 4 8}^{* *}$ & 1 \\
\hline
\end{tabular}

**. Correlation is significant at the 0.01 level (2-tailed)

Table 7: Results of correlation analysis between system success and job satisfaction

\subsection{FINDING AND DISCUSSION}

\subsection{Relationship between WILS success factor and job satisfaction}

One of the main objectives of this study is to examine the relationship between WILS success factor and job satisfaction. In the analysis, there are four independent variables were identified as WILS success factor including system quality, service quality, usage satisfaction, Internet quality and job satisfaction. These success factor have a relationship with job satisfaction and it is therefore all hypotheses in this study were accepted.

\subsection{Relationship between system quality and job satisfaction}

The findings reveal that there is a positive but low correlation between system quality and job satisfaction. Majority of WILS users are support staff with less than a year experience in using WILS. The respondents find it a bit difficult to adapt the system in a short amount of time because of the different features, integration, terms and structure. This might have an impact on their job satisfaction. Research conducted by Iivari (2005) shown a strong relationship between system quality and job satisfaction. Other than that, the features of information system which is one measure of system quality has been found to be significant related to job satisfaction (Gelderman, 2002).

\subsection{Relationship between service quality and job satisfaction}

Service quality was positively and moderately correlated with job satisfaction. The service quality factor shows significant relationship with job satisfaction as they support library staff need in term of providing advisory and guidance to get their job done. Leonard-Barton \& Sinha (1993) in their study found that the technical staff performance in response to user problem was positively related to job satisfaction. This is also supported by case study conducted by Leclercq (2007) which found the significant relationship between technical staff function and quality of service provided had an impact on the job satisfaction.

\subsection{Relationship between usage quality and job satisfaction}

It is also shown a positive relationship and high correlation between usage quality and job satisfaction. According to Agarwal \& Prasad (1999) user value the usefulness of new system with the support of training, technology awareness, accept the technology advancement based on their education, past experience, positive attitude and believe. Here, it was found that library staff are willing to learn more about handling WILS and intended to use in future as the evidence of great effort by the top management that send expert team to every campus. This initiative is implemented as to educate their staff in proper classroom training and hands on experience as well as details document in work instruction process. 


\subsection{Relationship between Internet quality and job satisfaction}

The relationship between Internet quality and job satisfaction was positive and moderate with correlation. The Internet quality factor shows significant relationship with job satisfaction as without it, WILS cannot run smoothly and fulfil respondent needs. As there are limited literature and quite a few studies conducted to explain the impact of Internet quality to system success, this study discovers that by using a web integrated library management system, Internet quality has a huge impact and relations towards job satisfaction. Fast speed, sufficient and stable Internet connection are critical in order to produce a platform for data to be access, process, retrieve, disseminate and share between one campus to another. Failure of any one of this requirement may lead to the data error, duplication, data corrupt and time consuming (Bouch, Kuchinsky \& Bhatti, 2000).

From the findings it shows that the performance and quality of WILS is still at moderate level. As for that reason, WILS needs to upgrade, modify, improve and customize its features to meet the library staff requirement. This study creates an opportunity for the evaluation and measurement which are important to be done as to check and balance WILS performance towards job satisfaction.

\subsection{CONCLUSION}

Several recommendations are suggested to improve the job satisfaction on web integrated library system in academic libraries. First, the future research on knowledge, attitude and practices (KAP studies) are proposed as to measure WILS in real situation, identify what is known or done and the effectiveness of WILS that affect staff behaviors and job performance. Second, staff who work with WILS are dealing with complex and subject to productivity pressure. Adequate training on every module is a must and has a long lasting impact on the morale and willingness for them to embrace technological change. Third, frequent audit should be conducted to verify secure operation of a system and its software. This process will determine if the information systems are safeguarding assets, maintaining data integrity, and operating effectively to achieve the academic libraries goals or objectives. Moreover, it helps to examine the library information system inputs, outputs, and processing. Fourth, academic libraries should encourage and motivate their staff on accepting the change to WILS as to be patient, open minded and cooperate together to contribute any ideas or necessary improvement. It is also suggested that, academic libraries to set up IT special force of expert team that consist of system analyse, system developer, programmer and information technology expert to look into issues of WILS technology, data structure and programming without sole dependencies to vendor.

The lesson learned from this study will support the improvement of WILS in future and acknowledge the challenges and success stories. It is also hope that academic libraries review WILS performance in term of system quality, information quality, service quality, usage quality and Internet quality on annual basis as to boost their staff job satisfaction.

To conclude, according to Knox (2014) not one single library management system is perfect and each new system installed at a library provides an opportunity for something to succeed or fail. We all learn something new every day and it was hope that all library staff would give themselves a chance to learn, adapt and adopt this new integrated system environment from their own efforts. We should support and accept the change and make full use of this new system and constantly give feedback within the selected community of practice as to come out with an effective solution. 


\section{REFERENCES}

Ahmad, P. \& Iqbal, J. (2009). Library automation of Al-Barkaat Institute of Management Studies, Aligarh with the help of Alice for Window (AFW) library software. Indian Journal of Library and Information Science, 3(2), 8186.

Agarwal, R., \& Prasad, J. (1999). Are individual differences germane to the acceptance of new information technologies? Decision Sciences, 30(2), 361-391.

Aggelidis, V. P., \& Chatzoglou, P. D. (2012). Hospital information systems: Measuring end user computing satisfaction (EUCS). Journal of biomedical informatics, 45(3), 566-579.

Babu, P. B. \& Krishnamurthy, M. (2013). Library automation to resource discovery: a review of emerging challenges. The Electronic Library, 31(4), 433-451.doi: http://dx.doi.org/10.1108/EL-11-2011-0159

Balnaves, E. (2008). Open source library management systems: a multidimensional evaluation. Australian Academic \& Research Libraries, 39(1), 1-13. doi:00330330810892703

Bills, L. (2000). Technical services and integrated library systems. Library HiTech, 18(2), 144-150. doi:10.1108/07378830010333509

Bissels, G. (2008). Implementation of an open source library management system: experiences with Koha 3.0 at the Royal Lodon Homoepatic Hospital. Program, 42(3), 303-314. doi:https://doi.org/10.1108/

Bouch, A., Kuchinsky, A., \& Bhatti, N. (2000). Quality is in the eye of the beholder: meeting users' requirements for Internet quality of service. In Proceedings of the SIGCHI conference on Human Factors in Computing Systems (297-304). ACM.

Bryman, A., \& Bell, E. (2015). Business research methods. Oxford: Oxford University Press.

Chaputula, A. and Kanyundo, A. (2019). Use of Koha-integrated library system by higher education institutions in Malawi. Digital Library Perspectives, 35(3), 117-141. doi:http://dx.doi.org/10.1108/DLP-07-2019-0028

Croft, B., Metzler, D., \& Strohman, T. (2010). Search engines: information retrieval in practice. New York: Pearson.

Dahl, K. (2002). Lund University Libraries and the move to Virtua in a networked environment. Program, 36(2), 110116. doi:http://dx.doi.org/10.1108/00330330210429154.

DeLone, W. H. \& McLean, E. R. (1992). Information systems success: the quest for the dependent variable. Information Systems Research, 3(1), 60-95.

DeLone, W. H. \& McLean, E. R. (2003). The DeLone and McLean model of information systems success: a ten-year update. Journal of Management Information Systems, 19(4),9-30.

George, D., \& Mallery, P. (2014). SPSS for Windows step by step: A simple guide and reference. India: Pearson.

Goodhue, D. L. \& Thompson, R. L. (1995). Task-technology fit and individual performance. MIS Quarterly, 19(2), 213-36.

Hair, J. F., Black, W. C., Babin, B. J., \& Anderson, R. E. (2014). Multivariate data analysis. Upper Saddle River, NJ: Prentice Hall.

Halawi, L. A., McCarthy, R. V., \& Aronson, J. E. (2008). An empirical investigation of knowledge management systems' success. Journal of Computer Information Systems, 48(2), 121-135.

Hanumappa, A., Dora, M. \& Navik, V. (2014) Open source software solutions in Indian libraries. Library Hi Tech, 32(3), 409-422. doi:http://dx.doi.org/10.1108/LHT-12-2013-0157

Hines, S., \& Matteson, M. L. (2017). Emotion in the library workplace. Bingley, U.K.: Emerald Publishing Limited. 
Huang, Y., Pu, Y., Chen, T. \& Chiu, P. (2015). Development and evaluation of the mobile library service system success model A case study of Taiwan. The Electronic Library, 33(6), 1174-1192. doi:http://dx.doi.org/10.1108/EL-06-2014-0094

$\mathrm{Hu}, \mathrm{X} .$, \& Wu, K. (2016). Assessing information technology systems in the environmental arena of China: A validation of the Delone and Mclean information systems success model. In Proceedings of the 17th International Digital Government Research Conference on Digital Government Research (276-280). ACM.

Joseph, P. \& Namjoo, C. (2013). A comparison between select open source and proprietary integrated library systems. Library Hi Tech, 31(3), 435-454. doi:http://dx.doi.org/10.1108/LHT-01-2013-0003

Judge, T. A., Zhang, S. C., \& Glerum, D. R. (2020). Job satisfaction. Essentials of Job Attitudes and Other Workplace Psychological Constructs, 207-241.

Kenchakkanavar, A. Y., \& Chavan, S. M. (2020). Job satisfaction of library and information science professionals: an overview. Library Philosophy and Practice.

Knox, K. C. (2014). Implementing technology solutions in libraries: Techniques, tools, and tips from the trenches. Medford: Information Today, Inc.

Madhusudhan, M. \& Singh, V. (2016). Integrated library management systems. The Electronic Library, 34(2), 223249. doi:http://dx.doi.org/10.1108/EL-08-2014-0127

McGrogy, M. et al. (2007). The impact of the integrated digital library system on the CNIB library. Library Trends, 55(4), 973-993.

Omeluzor, S. U., \& Oyovwe-Tinuoye, G. O. (2016). Assessing the adoption and use of integrated library systems (ILS) for library service provision in academic libraries in Edo and Delta states, Nigeria. Library Review, 65(8/9), 578-592. doi:http://dx.doi.org/10.1108/LR-01-2016-0005

Oyelude, A. A. (2016). Open source software for library systems-2. Library Hi Tech News, 33(9), 10-13. doi:https://doi.org/10.1108/LHTN-09-2016-0044

Parvez, M. (2011). Development in library services with the advent of ICTs based products and services: a continuous process. International Journal of Digital Library Services, 1(2), 2-8.

Perpustakaan Tun Abdul Razak. (2017). Perpustakaan UiTM. Retrieved from www.library.uitm.edu.my

Petter, S., \& McLean, E. R. (2009). A meta-analytic assessment of the DeLone and McLean IS success model: an examination of IS success at the individual level. Information \& Management, 46(3), $159-166$. doi:http://dx.doi.org/10.1016/j.im.2008.12.006

Ponterotto, J. G. (2005). Qualitative research in counseling psychology: A primer on research paradigms and philosophy of science. Journal of counseling psychology, 52(2), 126.

Roky, H., \& Meriouh, Y. A. (2015). Evaluation by users of an industrial information system (XPPS) based on the DeLone and McLean Model for IS success. Procedia Economics and Finance, 26, 903-913. doi:http://dx.doi.org/10.1016/S2212-5671(15)00903-X

Sekaran, U. \& Bougie R. (2010). Research methods for business: a skill building approach. Chichester: John Wiley $\&$ Sons

Shafique, F. \& Mahmood K. (2008). Integrated library software: a survey of Lahore. Library Hi Tech News, 25(6), 613. doi:http://dx.doi.org/10.1108/07419050810912805

Shaw, J.N. and De Sarkar, T. (2020). A cloud-based approach to library management solution for college libraries. Information Discovery and Delivery. doi:http://dx.doi.org/10.1108/IDD-10-2019-0076

Siddique, N. \& Mahmood, K. (2014). Library software in Pakistan. Library Review, 63(3), $224-240$. doi:http://dx.doi.org/10.1108/LR-04-2013-0048. 
Singh, M., \& Sanaman, G. (2012). Open source integrated library management systems: comparative analysis of Koha and NewGenLib. The Electronic Library, 30(6), 809-832. doi:https://doi.org/10.1108/02640471211282127

Singh, V. (2014). Expectations versus experiences: librarians using open source integrated library systems. The Electronic Library, 32(5), 688-709. doi:https://doi.org/10.1108/EL-10-2012-0129

Sorum, H., Medaglia, R., Normann, K., Murray, A. \& DeLone, S. W. (2012). Perceptions of information system success in the public sector: Webmasters at the steering wheel. Transforming Government: People, Process and Policy, 6(3), 239-257. doi:http://dx.doi.org/10.1108/17506161211251254

Tague-Sutcliffe, J. M. (1996). Some perspectives on the evaluation of information retrieval systems. Journal of the Association for Information Science and Technology, 47(1), 1-3. doi:10.1002/(SICI)10974571(199601)47:11::AID-ASI13.0.CO;2-3

Tam, C., \& Oliveira, T. (2016). Understanding the impact of m-banking on individual performance: DeLone \& McLean and TTF perspective. Computers in Human Behavior, 61, 233-244. doi:http://dx.doi.org/10.1016/j.chb.2016.03.016

Vasupongayya, S., Keawneam, K., Sengloilaun, K. \& Emmawat, P. (2011). Open source library management system software: a review. World Academy of Science, Engineering and Technology, 77(1), 973-978

Waljat, A. M., \& Mukherjee, S. (2010). A review of information system success models. International Journal of Innovative Research in Technology \& Science, 1(3), 15-18. Retrieved from http://ijirts.org/volume1issue3/IJIRTSV1I30009.pdf

Xinli, H. (2015). Effectiveness of information technology in reducing corruption in China: a validation of the DeLone and McLean information systems success model. The Electronic Library, 33(1), 52-64. doi:http://dx.doi.org/10.1108/EL-11-2012-0148

Zaied, A. N. H. (2012). An integrated success model for evaluating information system in public sectors. Journal of Emerging Trends in Computing and Information Sciences, 3(6), 814-825. Retrieved from www.cisjournal.org/journalofcomputing/archive/vol3no61.pdf 